\title{
円周切欠きを有する丸棒試験片におけるひずみ速度集中係数の提案 と応力集中係数の関係についての考察
}

\section{Strain rate concentration factor in comparison with stress concentration factor of a circumferential notch in a round bar specimen} \\ Nao-Aki NODA*1 ${ }^{*}$ Daichi AKAGI*2, Yunong SHEN ${ }^{* 2}$, Rei TAKAKI*3, \\ Tomohiro IKEDA ${ }^{* 4}$, Yoshikazu SANO ${ }^{* 5}$ and Yasushi TAKASE ${ }^{* 6}$ \\ ${ }^{* 1},{ }^{*} 2,{ }_{3},{ }^{*} 5,{ }^{* 6}$ Department of Mechanical and Control Engineering, Kyushu Institute of Technology \\ 1-1 Sensui-cho, Kitakyushu-shi, Fukuoka 804-8550, Japan \\ ${ }^{* 4}$ Hinode, Ltd. Research and Development Center \\ Azaiwasaki, Miyaki-cho, Miyaki-gun, Saga 849-0101, Japan
}

野田 尚昭*1, 赤木 大地 ${ }^{* 2}$, 沈 雨濃 ${ }^{* 2}$, 高木 怜*3 池田 朋弘 ${ }^{* 4}$, 佐野 義一 ${ }^{* 5}$, 高瀬 康 ${ }^{* 6}$

Received: 31 January 2017; Revised: 20 April 2017; Accepted: 11 June 2017

\begin{abstract}
High-speed tensile testing is now being recognized as a standard testing method for evaluating the impact strength of engineering materials. The impact speeds of Izod and Charpy tests cannot be controlled and therefore do not correspond to the real failure of real products. The brittle-ductile transition of structural materials is affected by the temperature and loading speed. In the high-speed tensile test, it is necessary to obtain the strain rate at the notch root accurately to understand the effect of impact load. For smooth specimens, the strain rate can be determined from the tensile speed $u / t$ and specimen length $l$ as $\dot{\varepsilon}_{\text {smooth }}=u / t l$. For notched specimens, however, the strain rate at the notch root $\dot{\varepsilon}_{\text {notch }}$ should be analyzed accurately. In this study, therefore, the strain rate concentration factor defined as $K_{t \dot{\varepsilon}}=\dot{\varepsilon}_{n o t c h} / \dot{\varepsilon}_{\text {smooth }}$ is studied with varying the notch geometry. To predict the strain rate concentration factor $K_{t \dot{\varepsilon}}$ accurately, the relationship between $K_{t \dot{\varepsilon}}$ and the stress concentration factor $K_{t}^{*}=\sigma_{\max } / \sigma_{\text {gross }}$ is investigated. Here, $\sigma_{\text {gross }}$ is the remote tensile stress and $P$ is the tensile load. It is found that the strain concentration factor $K_{t \dot{\varepsilon}}$ can be estimeted from stress concentration factor $K_{t}^{*}$ when the relative notch depth $2 t / D \leqq 0.5$ ( $\mathrm{t}$ : notch depth, $\mathrm{D}$ : the specimen diameter).
\end{abstract}

Key words : Tensile properties, Stress concentration, Notch, Impact strength, Strain rate

\section{1. 緒言}

構造用材料の強度・じん性はひずみ速度と温度によって変化し，特定の条件下で延性破壊から脆性破壊へと遷 移する。 このため各種構造物の設計においては，構造用材料の安全性を保証するためのひずみ速度と温度の上下 限值が指定されていることがある（岡下他，1998）（豊田，1996）。平滑試験片では延性を示寸温度でも，切欠き 等の応力集中部を有する場合に，脆性破壊を起こすことがあり，その原因は切欠き底で高いひずみ速度が生じる

No.17-00034 [DOI:10.1299/transjsme.17-00034], J-STAGE Advance Publication date : 23 June, 2017

*1 正員, フエロー, 九州工業大学 大学院工学研究院 機械知能工学研究系（广804-8550 福岡県北九州市戸畑区仙水町 1-1）

*2 九州工業大学 大学院 工学府

*3 学生員, 九州工業大学 大学院 工学府

*4 日之出水道機器（株）（厂849-0101＼cjkstart佐賀県三養基郡みやき町大字原古賀字岩崎 R\&D 総合センター）

*5 正員, 九州工業大学 大学院工学研究院 機械知能工学研究系

*6 正員，九州工業大学 戸畑・若松キャンパス技術部

E-mail of corresponding author: noda@mech.kyutech.ac.jp 
ためと考えられる. 一般に構造材料の衝撃試験として, シャルピ一衝撃試験が広く用いられている(瀬尾, 正木, 1982）（Tanguy et al., 2005）（Roebben et al., 2015）（Wang and Splett, 2005）。しかし，シャルピー衝撃試験は吸収エ ネルギーや勒性を評価するものであり, 工業製品の設計や製造に必要とされる引張強度, 而力や疲労限度などの 強度に直接には関係しない，また，衝撃速度を任意に設定することができないため，製品に要求される速度領域 における衝撃強度が評価できない，このような製品・材料開発者の経験から，近年では衝撃強度試験として，切 欠きを有する平板や丸棒の高速引張試験が多く用いられるようになっている（安藤他，2014）（Huh et al., 2008）

（Noda et al., 2015）（竹田，2008）。切欠き底でのひずみ速度は，試験片の温度と同様にその破壊形態の遷移に大 きな影響を及ぼすため, 高速引張試験では切欠き底のひずみ速度を知ることが重要である. 実験的に切欠き底の ひずみ速度を測定することは非常に困難であるため，切欠き試験片のひずみ速度集中係数を求めることができれ ば，引張速度から切欠き底のひずみ速度の算出が可能となる。

切欠き試験片の応力集中係数に関しては多くの研究がなされており，任意の切欠き寸法をもった試験片におけ る応力集中係数の計算式も提案されている（野田他，2010），しかし，ひずみ速度集中係数（野田他，2013）（安 藤他，2014）に関しては，そのような研究はほとんど見られない，そこで本研究では，切欠き半径と切欠き深さ がひずみ速度集中係数に及ぼす影響について調べ，既知の応力集中係数との関係を調べることによって，様々な $\mathrm{V}$ 字形切欠き形状における，ひずみ速度集中係数の予測を可能にすることを目的とする.

\section{2. ひずみ速度集中係数の定義（両側切欠きを有する平板試験片）}

ここではまず著者らが先の研究で行った，ひずみ速度集中係数の定義を紹介し，その問題点を示す．著者らは 先に, ポリカーボネートの衝撃強度を高速引張試験により引張速度と温度を変えて詳細に評価した (安藤他, 2014). そして，切欠き底のひずみ速度と破断ひずみの関係に対して，時間一温度換算則が適用することを示した。 これ よりマスターカーブを作成することで広範囲のひずみ速度域ならびに温度域に対応する延性／脆性破壊の予測を 可能にした．著者らは，切欠き効果を応力集中係数を用いて評価する場合と同様に，試験片最小断面のひずみ速 度分布に注目している，そこで，切欠き底において最大ひずみ速度 $\dot{\varepsilon}_{y A}=\dot{\varepsilon}_{m a x}$ が発生する時間 $t$ における，ひずみ 速度分布から最小断面の公称ひずみ速度 $\dot{\varepsilon}_{n o m}$ を求める. ついで切欠き底での最大ひずみ速度 $\dot{\varepsilon}_{y A}$ との比を求めて, ひずみ速度集中係数 $K_{t \dot{\varepsilon}}=\dot{\varepsilon}_{y A} / \dot{\varepsilon}_{n o m}$ を定義した（野田他，2013）。 $K_{t \dot{\varepsilon}}$ と $\dot{\varepsilon}_{y A}$ と $\dot{\varepsilon}_{n o m}$ の関係を図 1 (a)，(b) に示す. 図 1 (a) に, 任意の時間 $t$ での切欠き底のひずみ速度 $\dot{\varepsilon}_{y A}(t)$ と最小断面の公称ひずみ速度 $\dot{\varepsilon}_{n o m}(t)$ を示す.ここで, 解析に使用したポリカーボネートの機械的性質を表 1 に示す. 用いられた, 平板切欠き試験片は平行部長さ

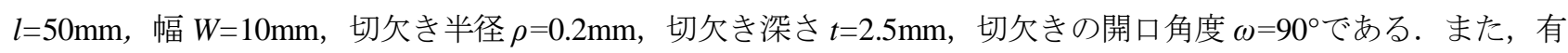
限要素法解析により求めた結果を図 1 (b) に, 任意の時間 $t$ における $K_{t \dot{\varepsilon}}(t)$ を $\rho=0.2 \mathrm{~mm}$ と $\rho=0.03 \mathrm{~mm}$ に対して示 寸. 図 1 (b) において, 異なる切欠き半径それぞれにおいて, $K_{t \dot{\varepsilon}}(t)$ が時間によらず常に一定であることが示さ れている.ここで，ひずみ速度は振動の収束値に注目しているため，図１（b）でひずみ速度集中係数は一定とな っている，以下でも，ひずみ速度の収束值に注目して計算を行っている（野田他，2013）。

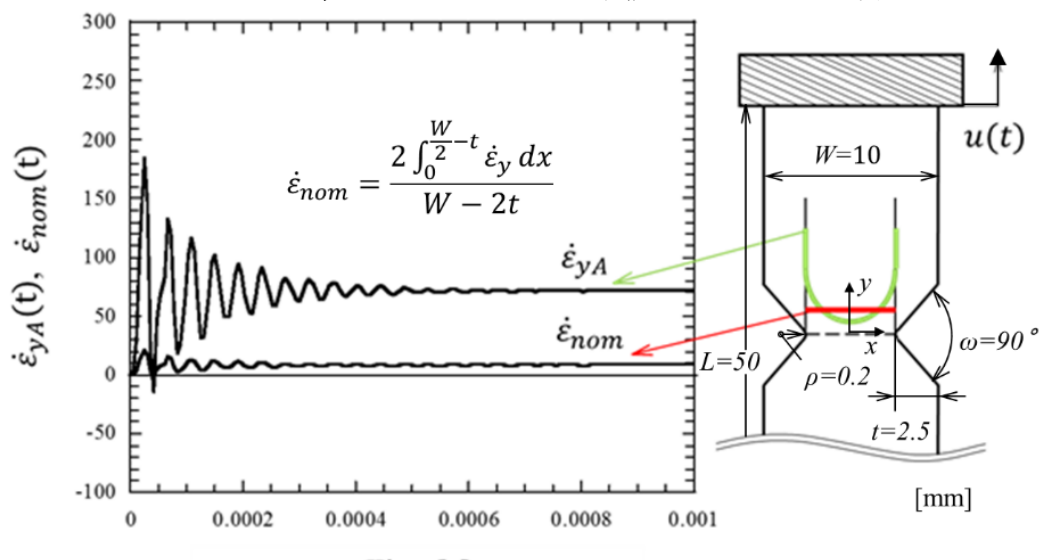

Time[s]

(a) Maximum strain rate and nominal strain rate.

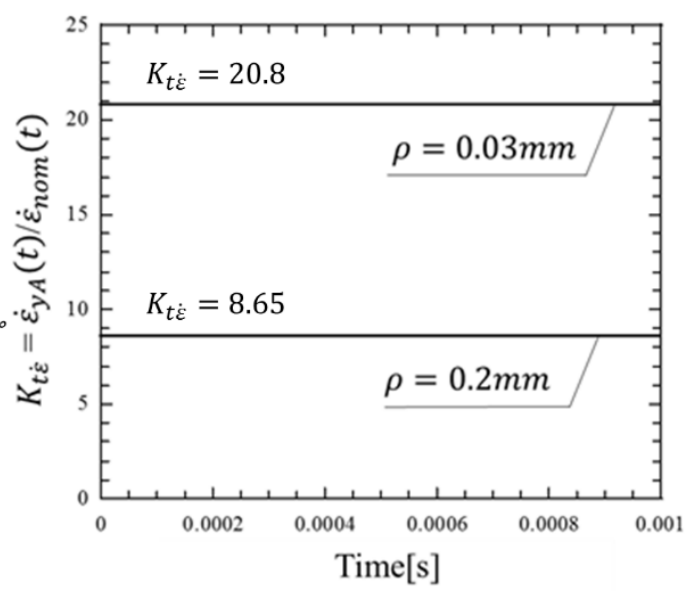

(b) Strain rate concentration factor.

Fig.1 Constancy of strain rate concentration factor (Plate specimen). 
Noda, Akagi, Shen, Takaki, Ikeda, Sano and Takase, Transactions of the JSME (in Japanese), Vol.83, No.851 (2017)

Table 1 Mechanical properties implemented in accordance with JIS K7161 and 7162.

\begin{tabular}{|c|c|c|c|c|}
\hline Material & $\begin{array}{c}\text { Yield stress } \\
\sigma_{y}[\mathrm{MPa}]\end{array}$ & $\begin{array}{c}\text { Stress at break } \\
\sigma_{b}[\mathrm{MPa}]\end{array}$ & $\begin{array}{c}\text { Stiffness } \\
E[\mathrm{GPa}]\end{array}$ & $\begin{array}{c}\text { Nominal strain at break } \\
\varepsilon_{b}[\%] \\
(\text { Gauge length=115[mm] })\end{array}$ \\
\hline PC & 62 & 73 & 2.3 & 111 \\
\hline
\end{tabular}

しかし，先の研究におけるひずみ速度集中係数の定義では，以下の問題点がある．ひずみ速度集中係数 $K_{t \dot{\varepsilon}}=$ $\dot{\varepsilon}_{y A} / \dot{\varepsilon}_{n o m}$ において，仮にひずみ速度集中係数 $K_{t \dot{\varepsilon}}$ が分かっていても，切欠き底におけるひずみ速度 $\dot{\varepsilon}_{y A}$ を求めるた めには, 最小断面の公称ひずみ速度 $\dot{\varepsilon}_{n o m}$ を知る必要がある. 図 2 (a) に示すように, 静的応力集中係数では公称 応力 $\sigma_{n o m}$ は荷重 $P$ と断面積（W-2t）により容易に求まるが，公称ひずみ速度 $\dot{\varepsilon}_{n o m}$ は図 $2 （ \mathrm{~b} ）$ に示すように最小 断面のひずみ速度分布を積分しその平均值を求めている. この方法では，切欠き形状ごとに最小断面のひずみ速 度分布は変化するため $\dot{\varepsilon}_{n o m}$ を求めることは容易ではない。

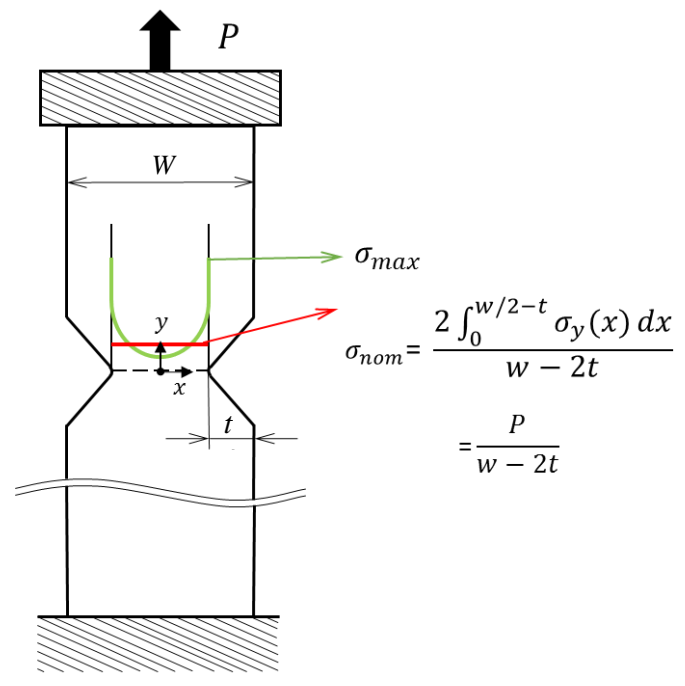

(a) $K_{t}=\sigma_{\max } / \sigma_{\text {nom }}$.

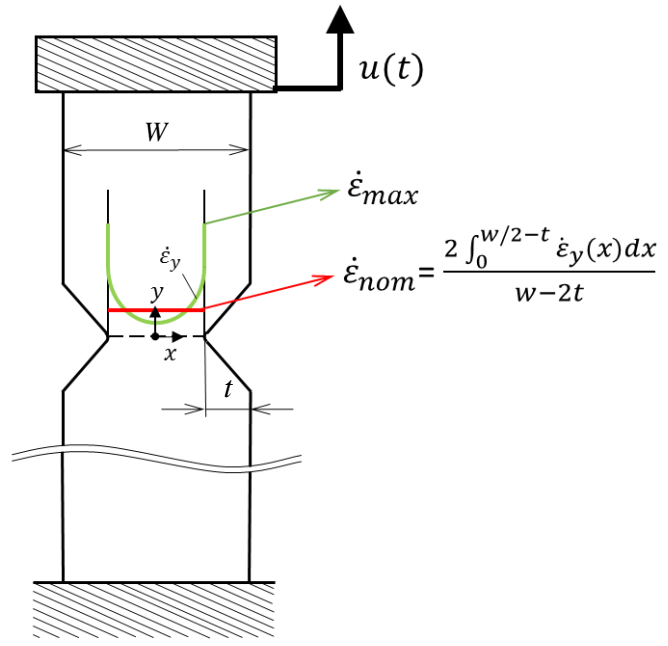

(b) $K_{t \dot{\varepsilon}}=\dot{\varepsilon}_{\text {max }} / \dot{\varepsilon}_{\text {nom }}$.

Fig.2 Nominal stress $\sigma_{\text {nom }}$ and nominal strain rate $\dot{\varepsilon}_{\text {nom }}$ (Plate specimen).

そこで，最小断面のひずみ速度分布の代わりに平滑材に生じるひずみ速度をもって基準にすることを考える. すなわち前述の $\dot{\varepsilon}_{y A} / \dot{\varepsilon}_{n o m}$ に代わって, 切欠き材の切欠き底の最大ひずみ速度と平滑材のひずみ速度との比によっ てひずみ速度集中係数を新たに定義する. 図 3 に引張速度と平滑材のひずみ速度の関係を, 試験片長さ $l=25,50$, $100 \mathrm{~mm}$ について示寸. 図 3 に示寸ように，平滑材のひずみ速度は引張速度に対して比例的に増加し式（1）で表 される.ここで, $u(t)$ は試験片に生じる変位 (図 $2(\mathrm{~b})$ 参照),$u(t) / t$ は引張速度, lは試験片長さ, $t$ は時間であ る.

$$
\dot{\varepsilon}_{\text {smooth }}=\frac{u(t) / l}{t}
$$

図 4 に切欠き試験片 $(\rho=0.2 \mathrm{~mm})$ と平滑試験片における $\dot{\varepsilon}_{\text {notch }}$ と $\dot{\varepsilon}_{s m o o t h}$ およびひずみ速度集中係数 $K_{t \dot{\varepsilon}}$ の引張速 度依存性を示す. $\dot{\varepsilon}_{\text {notch }}$ は FEM 解析, $\dot{\varepsilon}_{\text {smooth }}$ は式 (1) により求めた. 切欠き材, 平滑材とも引張速度に対して 比例して上昇するため, その比 $K_{t \dot{\varepsilon}}$ は引張速度に依存せず常に一定である. 寸なわち, ひずみ速度集中係数 $K_{t \dot{\varepsilon}}$ を 式 (2) のように切欠き材と平滑材の比として定義すると, 切欠き底でのひずみ速度は引張速度とひずみ速度集中 係数から求まる. 


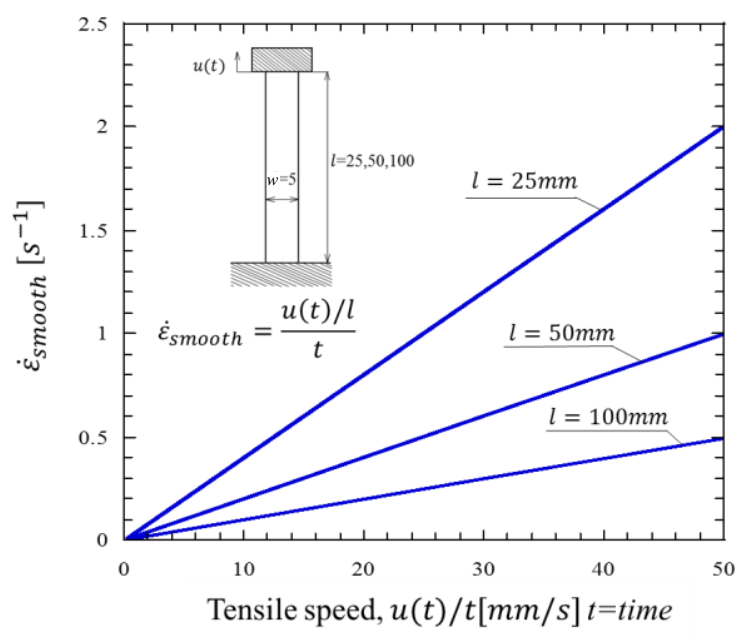

Fig.3 $\dot{\varepsilon}_{\text {smooth }}$ vs. tensile speed (Plate specimen).

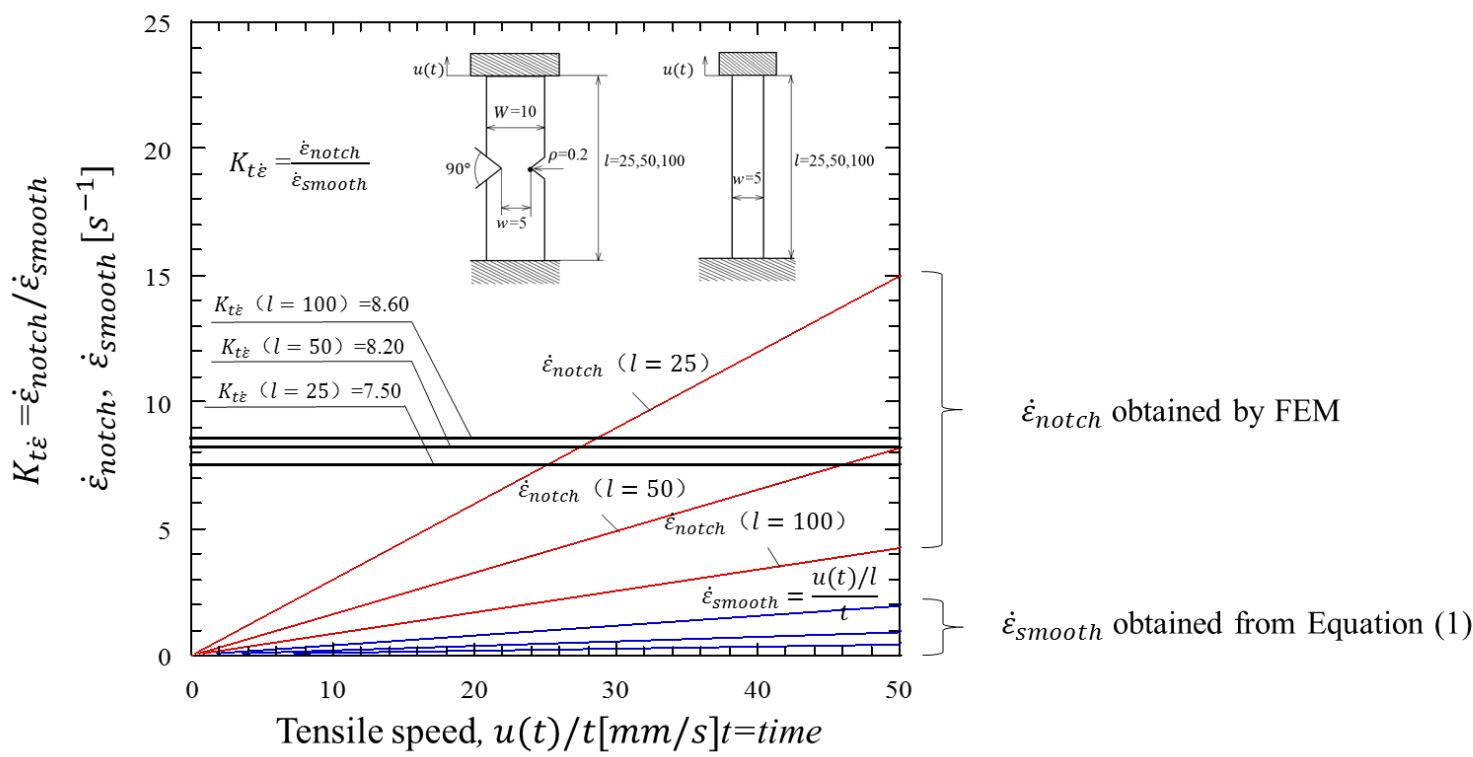

Fig.4 $K_{t \dot{\varepsilon}}=\dot{\varepsilon}_{\text {notch }} / \dot{\varepsilon}_{\text {smooth }}$ vs. tensile speed for different specimen length $l$.

$$
K_{t \dot{\varepsilon}}=\frac{\dot{\varepsilon}_{\text {notch }}}{\dot{\varepsilon}_{\text {smooth }}}, \quad \dot{\varepsilon}_{\text {notch }}=K_{t \dot{\varepsilon}} \cdot \dot{\varepsilon}_{\text {smooth }}=K_{t \dot{\varepsilon}} \cdot \frac{u(t) / l}{t}
$$

式（2）のようにひずみ速度集中係数 $K_{t \varepsilon}$ を定義すると，切欠き材最小断面の公称ひずみ速度 $\dot{\varepsilon}_{n o m}$ を求める必要は なくなる，なお図 4 に示すように，ひずみ速度集中係数 $K_{t \dot{\varepsilon}}$ は切欠き相対深さ $2 t / W$ のみならず，試験片長さ $l / W$ にも影響をうける．この点は応力集中係数 $K_{t}$ とは異なるので注意が必要である. なお，先の研究で高速引張試験 の試験範囲である $10^{5} \mathrm{~mm} / \mathrm{s}$ 以下ではひずみ速度が引張速度に比例していることが明らかとなっている（野田他， 2013). よって，今回は低速での解析を行ったが，高速での解析においても同じ傾向が現れると考えられる.

\section{3. ひずみ速度集中係数に及ぼす切欠き半径と深さの影響（円周切欠きを有する丸棒試験片）}

\section{$3 \cdot 1$ 円周切欠きを有する丸棒試験片と解析モデルおよび解析方法}

通常の引張強さの測定には, 丸棒試験片が用いられるので, ここでは円周切欠きを有する丸棒を対象とする. 図 5 に本研究で考察する丸棒切欠き試験片の形状寸法とその解析モデルを示す．ここでは, JIS Z 2241 に規定さ れている平滑丸棒の引張試験片を参考に, 図 5 (a) に示すように平行部長さ $l=40 \mathrm{~mm}$, 直径 $D=8 \mathrm{~mm}$ を固定する. また，切欠きの開き角は $\omega=45^{\circ}$ とし，切欠き半径 $\rho=0.25 \mathrm{~mm}$ と $\rho=2 \mathrm{~mm}$ に対して，切欠き深さを $t=1 \mathrm{~mm} \sim 3.96 \mathrm{~mm}$ 
と変化させて考察する. ここで $\rho=0.25 \mathrm{~mm}$ はシャルピー衝撃試験片の切欠き半径に対応する. また, $\rho=2 \mathrm{~mm}$ は 鋳鉄製品における最も鋭いコーナー部の半径に対応する（池田他，2016）（JIS B 0703）. 図 5 (c) に $\rho=0.25 \mathrm{~mm}$ の, 図 $5(\mathrm{~d})$ に $\rho=2 \mathrm{~mm}$ それぞれの解析モデルと切欠き底の拡大図を示す. 切久き底での最小メッシュサイズ $e$ は $e=\rho / 243$ であり, 図 5 (c), (d) を用いた応力集中係数の解析結果は, 精度の高い体積力法に準じる高い精度を 有する計算式（野田，2010）により算出した応力集中係数に対して誤差 1\%以内となっており，十分な精度を有 する. 図 5 (c), (d) の軸対称 FEM モデルの片方の端部を固定して, 一方の端部に変位 $1 \mathrm{~mm}$, 引張速度 $20 \mathrm{~mm} / \mathrm{s}$ と境界条件を設定して解析を行った。

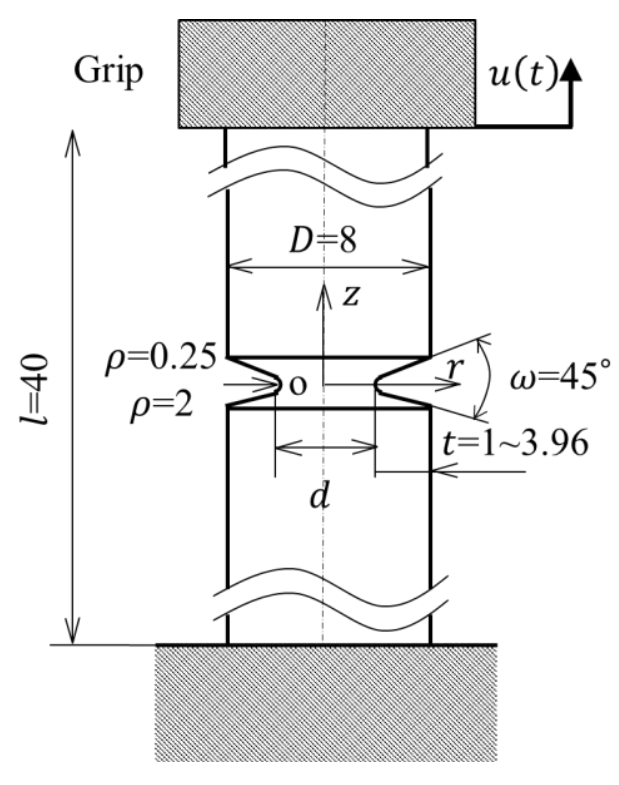

(a) Notch specimen.
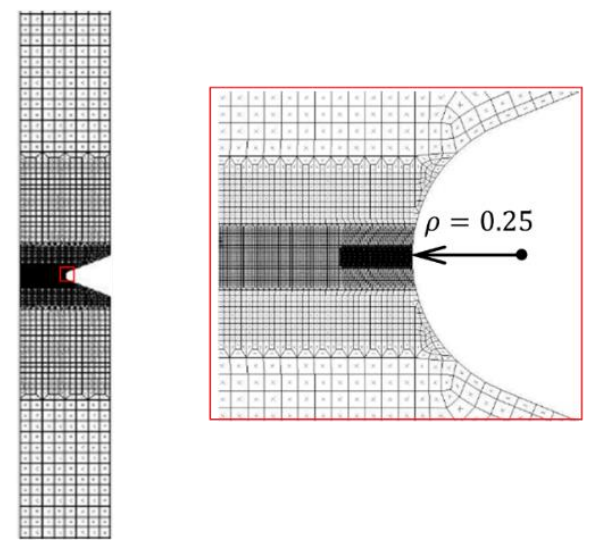

(c) FEM model and notch root detail $(\rho=0.25 \mathrm{~mm})$.

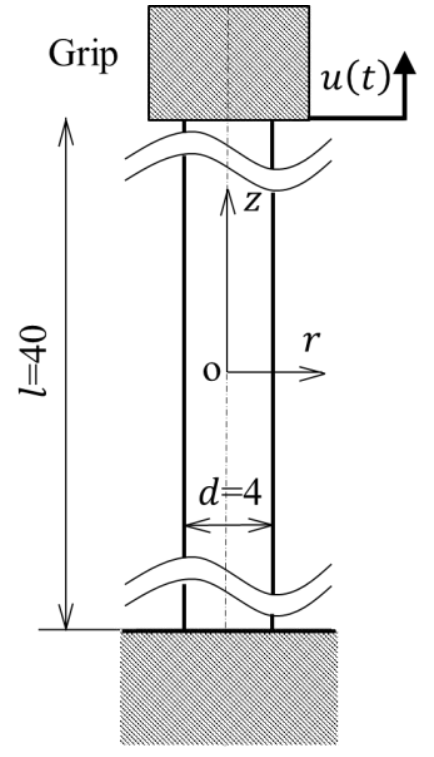

(b) Smooth specimen.
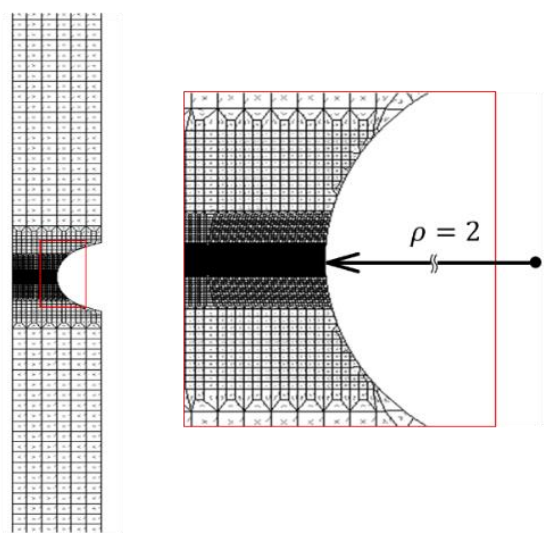

(d) FEM model and notch root detail $(\rho=2 \mathrm{~mm})$.

Fig.5 Geometry of specimens and FEM models (Unit: $\mathrm{mm}$ ).

\section{$3 \cdot 2$ 解析結果}

表 2 と図 6 (a) に切欠き半径の相対值 $2 \rho / D=0.0625$ と $2 \rho / D=0.5$ について切久きの相対深さの $2 t / D$ を変化 させてひずみ速度集中係数 $K_{t \dot{\varepsilon}}$ を求めた結果を示す. ここで $2 \rho / D=0.0625(\rho=0.25 \mathrm{~mm}, D=8 \mathrm{~mm})$ はシャルピ 一衝撃試験における試験片の切欠き半径 $\rho=0.25 \mathrm{~mm}$ に対応し, $2 \rho / D=0.5(\rho=2 \mathrm{~mm}, D=8 \mathrm{~mm})$ は鋳鉄製品 における最も鋭いコーナー部半径 $\rho=2 \mathrm{~mm}$ に対応する（池田他, 2016). 図 6 (a) より, 切欠き相対深さ $2 t / D$ の 増加に伴いひずみ速度集中係数 $K_{t \dot{\varepsilon}}$ も増加し, $2 t / D \rightarrow 1$ で $K_{t \dot{\varepsilon}} \rightarrow \infty$ となる. 比較のため, 応力集中係数 $K_{t}$ と切久き の相対深さ $2 t / D$ との関係も表 3 と図 6 (b) に合わせて示す. 一方, 応力集中係数 $K_{t}$ は $K_{t}=\sigma_{\max } / \sigma_{n e t}, \sigma_{n e t}=$ 
$4 P / \pi d^{2}$ で表されるので, $2 t / D \rightarrow 1 て ゙ K_{t} \rightarrow 1$ となる. また, $2 \rho / D$ を固定しているので, $2 t / D=0$ は平滑材に相当 するので, ひずみ速度集中係数 $K_{t \dot{\varepsilon}}=1$, 応力集中係数 $K_{t}=1$ となる.

Table 2 Strain rate concentration factor and stress concentration factor.

\begin{tabular}{|c|c|c|c|c|}
\hline \multirow{2}{*}{$2 t / D$} & \multicolumn{2}{|c|}{$K_{t \dot{\varepsilon}}$} & \multicolumn{2}{c|}{$K_{t}$} \\
\cline { 2 - 5 } & $\begin{array}{c}2 \rho / D \\
=0.0625\end{array}$ & $\begin{array}{c}2 \rho / D \\
=0.5\end{array}$ & $\begin{array}{c}2 \rho / D \\
=0.0625\end{array}$ & $\begin{array}{c}2 \rho / D \\
=0.5\end{array}$ \\
\hline 0.00 & 1.000 & 1.000 & 1.000 & 1.000 \\
0.25 & 5.581 & 2.554 & 3.550 & 1.619 \\
0.50 & 9.490 & 4.145 & 3.185 & 1.420 \\
0.75 & 18.50 & 8.334 & 2.334 & 1.204 \\
0.90 & 38.00 & 17.19 & 1.610 & 1.086 \\
0.99 & 167.0 & 63.06 & 1.070 & 1.008 \\
$\rightarrow 1.00$ & $\rightarrow \infty$ & $\rightarrow \infty$ & $\rightarrow 1.000$ & $\rightarrow 1.000$ \\
\hline
\end{tabular}

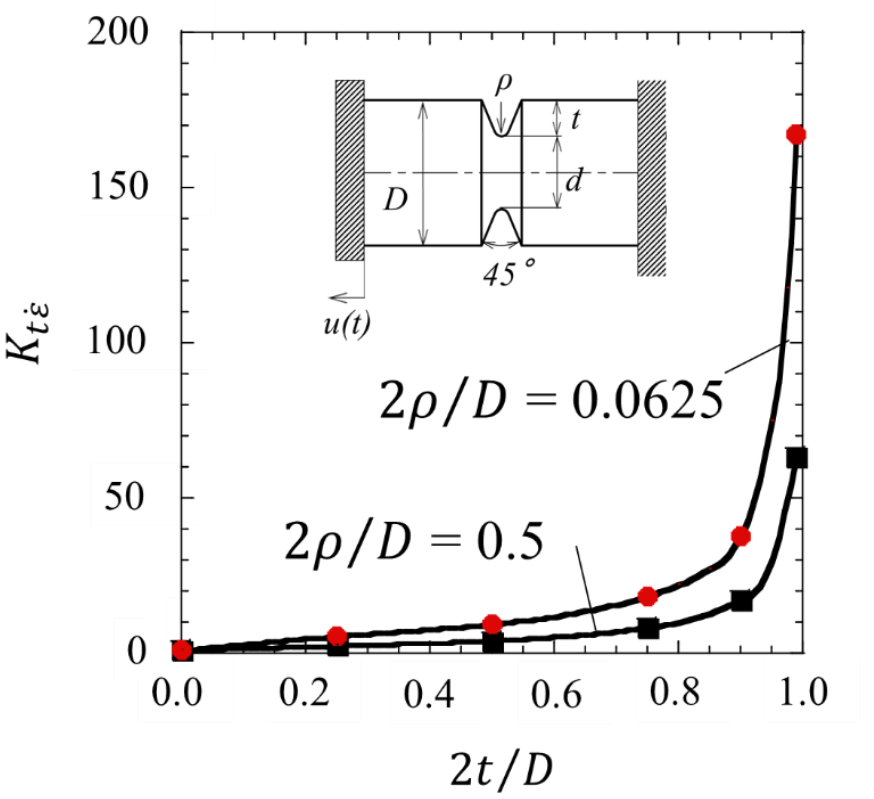

(a) Relationship between $K_{t \dot{\varepsilon}}$ and notch depth.

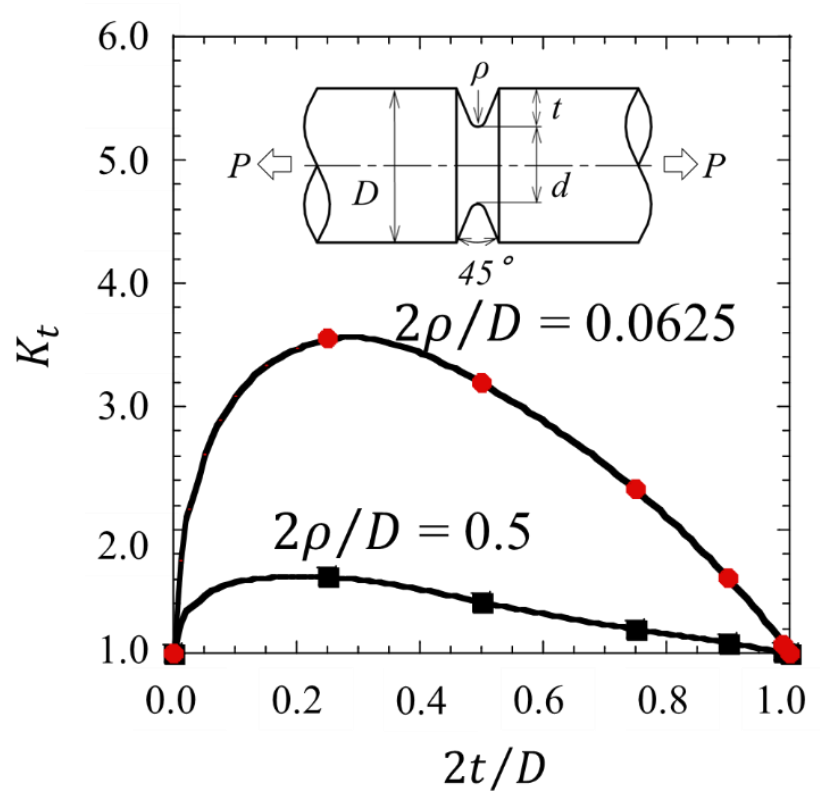

(b) Relationship between $K_{t}$ and notch depth.

Fig.6 $K_{t \dot{\varepsilon}}$ vs. $2 t / D$ and $K_{t}$ vs. $2 t / D$.

表 3 と図 7 にひずみ速度集中係数と応力集中係数の比と切欠き相対深さの関係を示す. 切欠き相対深さ $2 t / D \rightarrow$ 1 で, ひずみ速度集中係数と応力集中係数の比 $K_{t \dot{\varepsilon}} / K_{t} \rightarrow \infty$ となる. ここで, 応力集中係数は式 (3) に示すように, 最大応力 $\sigma_{\text {max }}$ と最小断面の公称応力 $\sigma_{n e t}$ との比である. 図 6 (a), (b) を比較して分かるように, 切欠き相対深さ $2 t / D \rightarrow 1$ で, ひずみ速度集中係数 $K_{t \dot{\varepsilon}} \rightarrow \infty$, 応力集中係数 $K_{t} \rightarrow 1$ となる. そこで, 最大応力 $\sigma_{\text {max }}$ と平滑部での平均 応力 $\sigma_{\text {gross }}$ との比を式 (4) に示すように $K_{t}^{*}=\sigma_{\max } / \sigma_{\text {gross }}$ と定義してひずみ速度集中係数との関係を調べる.

$$
K_{t}=\frac{\sigma_{\max }}{\sigma_{\text {net }}}
$$




$$
K_{t}^{*}=\frac{\sigma_{\max }}{\sigma_{\text {gross }}}=K_{t} \cdot\left(\frac{D}{d}\right)^{2}, \sigma_{\text {gross }}=\sigma_{\text {net }} \cdot\left(\frac{d}{D}\right)^{2}
$$

Table 3 Ratio of strain rate concentration factor and stress concentration factor.

\begin{tabular}{|c|c|c|c|c|}
\hline \multirow{2}{*}{$2 t / D$} & \multicolumn{2}{|c|}{$K_{t \dot{\varepsilon}} / K_{t}$} & \multicolumn{2}{c|}{$K_{t \dot{\varepsilon}} / K_{t}^{*}$} \\
\cline { 2 - 5 } & $\begin{array}{c}2 \rho / D \\
=0.0625\end{array}$ & $\begin{array}{c}2 \rho / D \\
=0.5\end{array}$ & $\begin{array}{c}2 \rho / D \\
=0.0625\end{array}$ & $\begin{array}{c}2 \rho / D \\
=0.5\end{array}$ \\
\hline 0.00 & 1.000 & 1.000 & 1.000 & 1.000 \\
0.25 & 1.572 & 1.574 & 0.884 & 0.889 \\
0.50 & 2.979 & 2.923 & 0.745 & 0.730 \\
0.75 & 7.940 & 6.958 & 0.498 & 0.435 \\
0.90 & 23.60 & 15.77 & 0.238 & 0.158 \\
0.99 & 156.1 & 62.44 & 0.0156 & 0.00627 \\
$\rightarrow 1.00$ & $\rightarrow \infty$ & $\rightarrow \infty$ & $\rightarrow 0.000$ & $\rightarrow 0.000$ \\
\hline
\end{tabular}

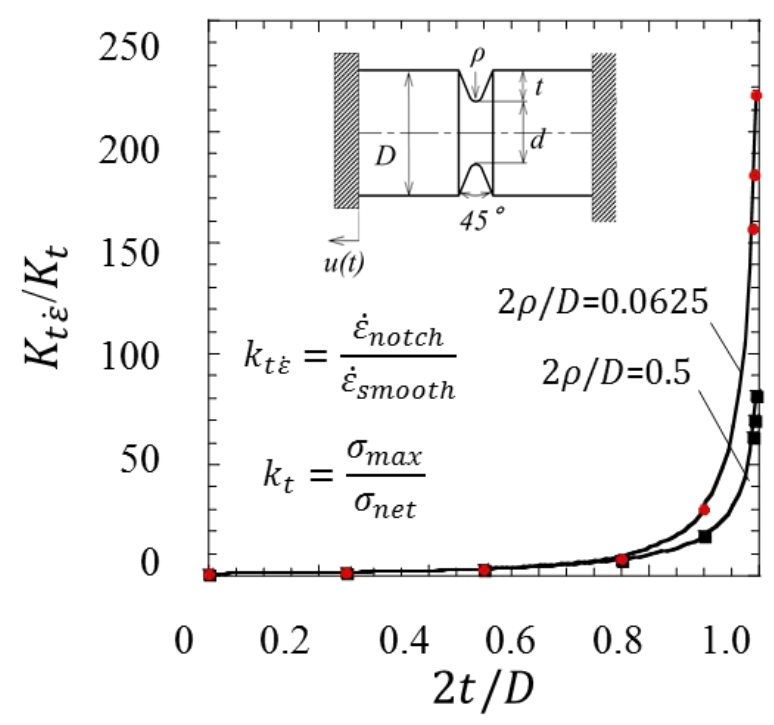

Fig.7 Relationship between $K_{t \dot{\varepsilon}} / K_{t}$ and notch depth.

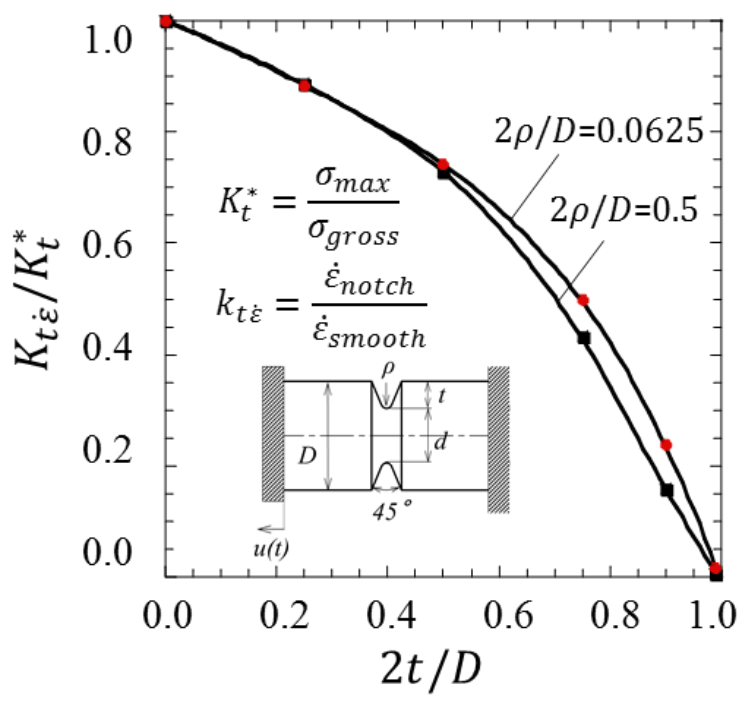

Fig.8 Relationship between $K_{t \dot{\varepsilon}} / K_{t}^{*}$ and notch depth.

表 3 と図 8 にひずみ速度集中係数 $K_{t \dot{\varepsilon}}$ と $K_{t}^{*}$ の比と切久き相対深さ $2 t / D$ の関係を示す. $2 t / D \leqq 0.5$ の範囲で $K_{t \dot{\varepsilon}} / K_{t}^{*}$ の值は $2 \rho / D=0.0625$ と $2 \rho / D=0.5$ で $2 \%$ 程度以内の誤差で一致していることがわかる. このことから， $K_{t \dot{\varepsilon}} / K_{t}^{*}$ の值は $2 t / D \leqq 0.5$ の範囲で切欠き半径に依存せず切欠き相対深さのみに依存するので，ひずみ速度集中係数を求 める際に, 応力集中係数を求めて $K_{t}^{*}$ を知ることにより, 図 8 よりひずみ速度集中係数を容易に予測することが可 能である.

\section{$3 \cdot 3$ ひずみ速度集中係数の相似性}

ここでは，応力集中係数 $K_{t}$ が相似形状において等しいことが知られているので，図 9 に示すように相似な切欠 き試験片形状におけるひずみ速度集中係数について調べた，その結果を表 4 に示寸，表 4 からわかるように，ひ ずみ速度集中係数は応力集中係数と同様に相似な試験片では一致することがわかる．これより，ひずみ速度集中 係数は試験片の大小によらないことが確認された. 


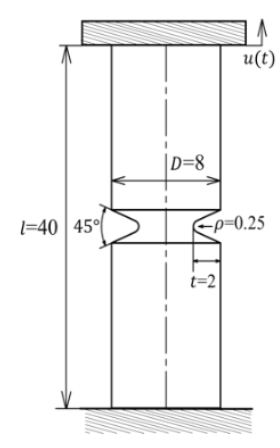

(a) Specimen 1 .

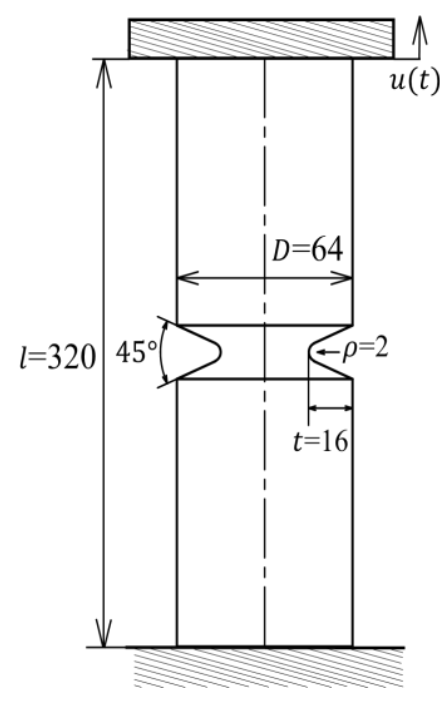

(b) Specimen $2($ Specimen $1 \times 8)$.

Fig.9 Similar specimen

Table 4 Similarity of strain rate concentration factor $K_{t \dot{\varepsilon}}$ in Fig.9 specimen.

\begin{tabular}{|c|c|c|}
\hline & Specimen 1 & Specimen 2 \\
\hline$\dot{\varepsilon}_{\text {notch }}$ & $0.215\left[\mathrm{~s}^{-1}\right]$ & $1.726\left[\mathrm{~s}^{-1}\right]$ \\
\hline$\dot{\varepsilon}_{\text {smooth }}$ & $0.0313\left[\mathrm{~s}^{-1}\right]$ & $0.250\left[\mathrm{~s}^{-1}\right]$ \\
\hline$K_{t \dot{\varepsilon}}=\frac{\dot{\varepsilon}_{\text {notch }}}{\dot{\varepsilon}_{\text {smooth }}}$ & 6.896 & 6.902 \\
\hline
\end{tabular}

\section{4. ひずみ速度集中係数の適用例}

最近構造用材料の一部として適用が進められている高 $\mathrm{Si}$ 球状黒鉛鋳鉄を, ひずみ速度集中係数の一つの適用例 として考察する（池田他，2016）。ここで，高 Si 球状黒鉛鋳鉄の機械的性質を表 5 に示寸．ここでは図 9 で平行 部長さ $l=40 \mathrm{~mm}$, 直径 $D=8 \mathrm{~mm}$, 切欠きの開口角度 $\omega=45^{\circ}$, 切久き半径 $\rho=0.25 \mathrm{~mm}$, 切欠き深さを $t=2 \mathrm{~mm}$ と固定 して, 種々の温度と引張速度で試験を行った. 図 10 に, この場合の切欠き試験片と平滑試験片における $\dot{\varepsilon}_{\text {notch }}$, $\dot{\varepsilon}_{\text {smooth }}$ と引張速度との関係および, ひずみ速度集中係数 $K_{t \dot{\varepsilon}}$ の引張速度の関係を示す.

Table 5 Mechanical properties implemented in accordance with JIS Z 2241.

\begin{tabular}{|c|c|c|c|c|}
\hline Material & $\begin{array}{c}\text { Tensile strength } \\
\sigma_{B}[\mathrm{MPa}]\end{array}$ & $\begin{array}{c}0.2 \% \text { proof stress } \\
\sigma_{b}[\mathrm{MPa}]\end{array}$ & $\begin{array}{c}\text { Stiffness } \\
E[\mathrm{GPa}]\end{array}$ & $\begin{array}{c}\text { Fracture strain } \\
\varepsilon_{b}[\%]\end{array}$ \\
\hline SSFDI500 & 525 & 401 & 172 & 21 \\
\hline
\end{tabular}




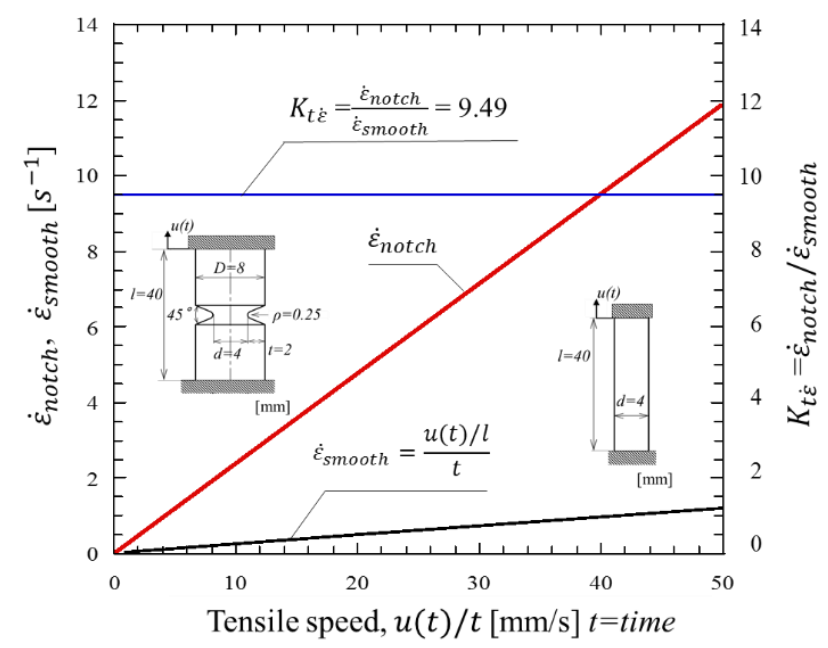

Fig. $10 \quad K_{t \dot{\varepsilon}}$ vs. tensile speed.

図 10 に示すように，上記切欠き試験片のひずみ速度集中係数 $K_{t \dot{\varepsilon}}$ は $K_{t \dot{\varepsilon}}=9.49$ であるので，これより任意の引張 速度 $u(t) / t$ の切欠き底でのひずみ速度 $\dot{\varepsilon}_{n o t c h}$ を式（2）より求めることができる．表 6 に，高 $\mathrm{Si}$ 球場黒鉛鋳鉄の試 験温度 $T=25^{\circ} \mathrm{C}$ と固定した場合の, それぞれの引張速度 $u(t) / t$ に対する引張強度 $\sigma_{B n o t c h}=4 P / \pi d^{2}$ の試験結果を, 切 欠き底でのひずみ速度 $\dot{\varepsilon}_{n o t c h}$ と併せて示す。また図 11 に，温度一定でのひずみ速度 $\dot{\varepsilon}_{n o t c h}$ と張強度 $\sigma_{B n o t c h}$ の関 係を示す. 図 11 より，引張強度はひずみ速度とともに上昇していくけれども，ひずみ速度がおよそ $4.3\left[\mathrm{~s}^{-1}\right]$ を境に 脆化して低下していることが分かる. 一方, 図 12 はひずみ速度が一定で, 温度を変化させた引張強さ試験の結果 である. 図 12 から分かるように, 引張強度はおよそ－ $25^{\circ} \mathrm{C}$ を境に脆化し，温度低下とともに低下している。

Table 6 Results of high speed tensile test of high Si ductile cast iron $\left(T=25\left[{ }^{\circ} \mathrm{C}\right]\right)$.

\begin{tabular}{|c|c|c|}
\hline $\begin{array}{c}\text { Tensile speed } \\
u(t) / t[\mathrm{~mm} / \mathrm{s}]\end{array}$ & $\begin{array}{c}\text { Strain rate at the } \\
\text { notch root } \\
\dot{\varepsilon}_{\text {notch }}\left[\mathrm{s}^{-1}\right]\end{array}$ & $\begin{array}{c}\text { Tensile strength } \\
\dot{\sigma}_{\text {Bnotch }}[\mathrm{MPa}]\end{array}$ \\
\hline \hline 0.0100 & 0.0024 & 762 \\
\hline 0.8400 & 0.1993 & 836 \\
\hline 18.1000 & 4.2942 & 876 \\
\hline 46.3000 & 10.9847 & 786 \\
\hline
\end{tabular}

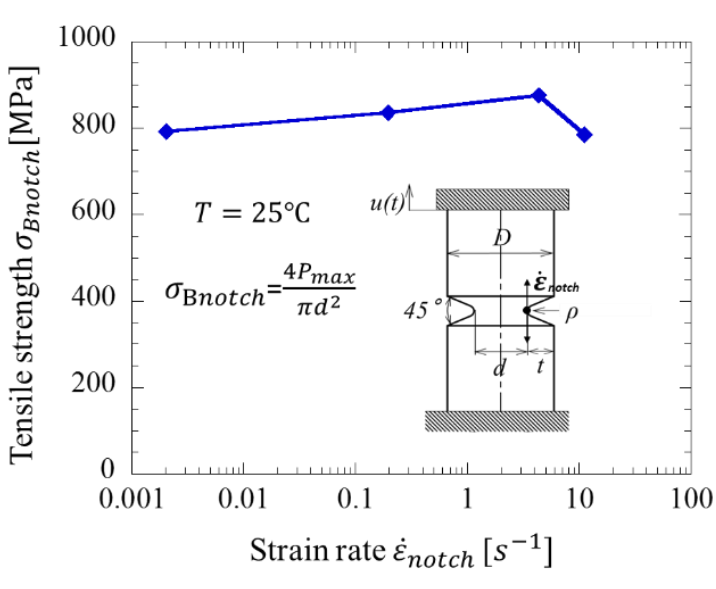

Fig.11 Effect of strain rate at the notch root on the tensile strength.

次に，ひずみ速度と温度の影響を統一的に評価するために，式（5）に示すひずみ速度一温度パラメータ $R$ 值 （Strain rate-temperature parameter）を用い，引張強度 $\sigma_{\text {Bnotch }}$ を整理した.

$$
R=T \ln \left(\frac{A}{\dot{\varepsilon}_{\text {notch }}}\right)
$$




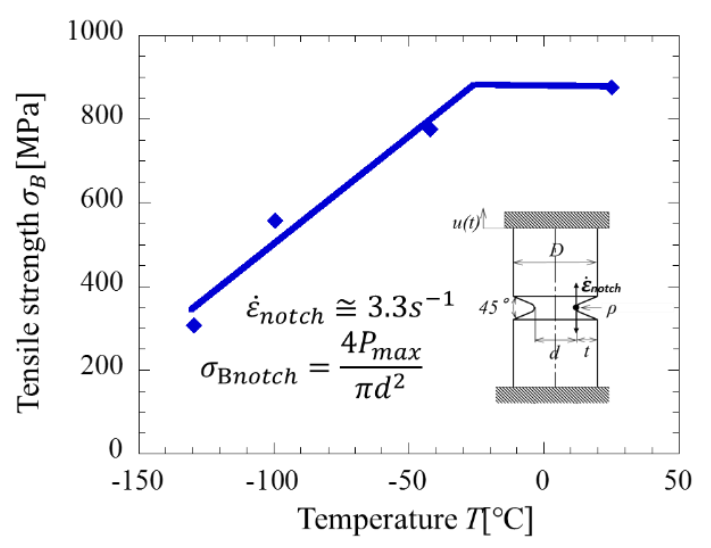

Fig.12 Effect of temperature on the tensile strength.

ここで， $T$ は試験温度，A は材料定数である（山本他，1999）（Bennett and Sinclair，1966）Ｒ值は，ひずみ速度の 影響を試験温度の影響と等価なものとして置き換えたものである. Bennett らにより，鋼材などの bcc 金属におい て，降伏点のひずみ速度 - 温度依存性を $R$ 值により整理できることが示され（Bennett and Sinclair, 1966), その 後, 藤井等や後藤等（藤井，1985）（後藤，1994）によって実験的にも裏付けされている.また，降伏点だけで なく引張強度も同様に整理できることが実験的に報告されており（南他，1998）, 鋳鉄材においては，フェライト 基地球状黒鉛鋳鉄の引張強度，降伏点（耐力）も $R$ 值と良い相関があることが報告されている（山本他，1999）。

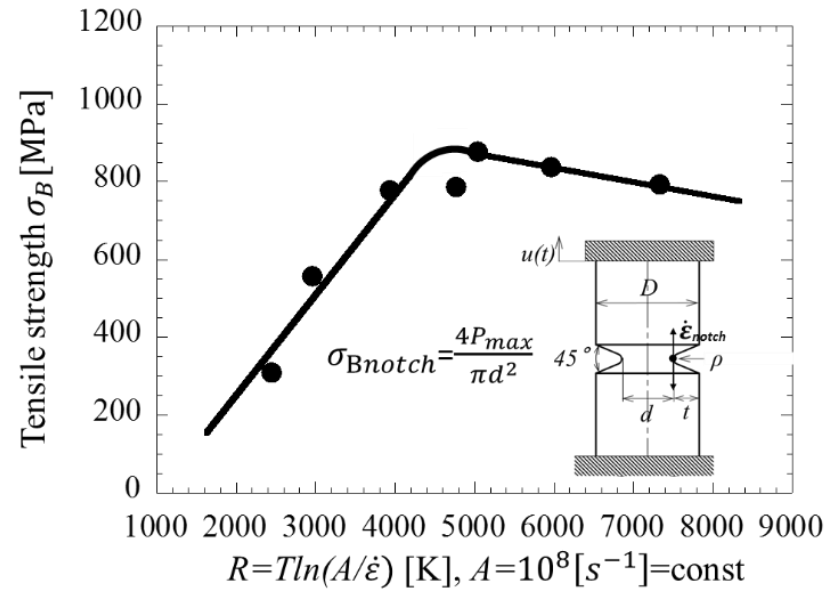

Fig.13 Relationship between tensile strength of notch root and R-value.

図 11，12 の結果を式（5）の $R$ 值により整理すると図 13 のように統一的に示すことが出来る. 図 13 より, $R$ の低下に伴い引張強度が上昇し, $R=5000$ 以下では $R$ の低下に伴い引張強度が低下し始めることが分かる. 以上 より, 本実験範囲のひずみ速度 $\left(10^{0} \sim 10^{-4} / \mathrm{s}\right)$ と温度 $\left(-130 \sim 25^{\circ} \mathrm{C}\right)$ の範囲では, 強度の遷移を $R$ 值により整理す ることができた．ところで今回の試験片の切欠き形状では, 切欠き材は平滑材に比べて 9.49 倍のひずみ速度を持 つことができた。これは $R$ 值をおよそ 600 下げるものであり，温度をおよそ $35^{\circ} \mathrm{C}$ 下げることと等価である.

\section{5. 結 言}

本論文では, 最近シャルピー衝撃試験に代わって用いられるようになっている高速引張試験において, 必要と なる切欠き底でのひずみ速度集中について考察した. 特に, ひずみ速度集中係数と応力集中係数との関係を切欠 き半径と切欠き深さを変えて調べた，それらの結果を図表にまとめた他，以下の結論が得られた. 
（1）ひずみ速度集中係数 $K_{t \dot{\varepsilon}}$ を，切欠き材と平滑材のひずみ速度の比により定義した．これによりひずみ速度集 中係数を求めておけば, 切欠き底に生じる最大ひずみ速度㐫は, 引張速度 $u(t) / t$ から $\dot{\varepsilon}=u(t) /(l t) \times K_{t \dot{\varepsilon}}$ に より容易に求めることができる.

（2）ひずみ速度集中係数 $K_{t \dot{\varepsilon}}$ は応力集中係数 $K_{t}$ と同様に，試験片形状が相似であれば，同じ値となる.

(3) ひずみ速度集中係数 $K_{t \dot{\varepsilon}}$ と応力集中係数 $K_{t}$ の比の值は, 切欠き相対深さ $2 t / D \leqq 0.5$ の範囲では, 切欠き深さの 相対值 $2 t / D$ の值によってほぼ決まる.この関係を用いれば, 応力集中係数 $K_{t}$ よりひずみ速度集中係数 $K_{t \dot{\varepsilon}}$ の 予測が可能になった.

なお, 応力集中係数は弾性解析で行うのが一般的である. 先の研究（野田他，2017）で，弾性解析と弾塑性解 析のマスターカーブの比較から, 弾塑性変形における延性・脆性破壊の遷移点の予測は解析の容易な弾性解析で も可能となることが明らかになっている. よってこの研究においても, 弾性解析を用いて解析を行っている.

\section{文献}

安藤誠人, 野田尚昭, 黒島義人, 石川康弘, 竹田英俊, ポリジメチルシロキサンを共重合したポリカーボネートの 衝撃特性と時間 - 温度換算則の適用, 日本機械学会論文集, Vol.80, No.814(2014), DOI: 10.1299/transjsme.2014smm0149.

Bennett, P. E. and Sinclair, G. M., Parameter representation of low-temperature yield behavior of body-centered cubic transition metals, Transactions of the ASME, Vol.65 (1966), pp.518-524.

藤井英輔, 大熊勇, 川口喜昭, 塚本雅敏, 鋼材の動的破壊勒性特性における温度および歪速度の影響の検討, 日本 造船学会論文集, No.158(1985), pp.619-629.

後藤浩二, 平澤宏章, 豊貞雅宏, ひずみ速度, 温度を考慮した構造用鋼構成方程式の簡易推定法, 日本造船学会論 文集, No.176(1994), pp.501-507.

Huh, H., Kim, S.B., Song, J.H. and Lim, J.H., Dynamic tensile characteristics of TRIP-type and DP-type steel sheets for an auto-body, International Journal of Mechanical Sciences, Vol.50 (2008), pp.918-931.

池田朋弘, 梅谷拓郎, 甲斐信博, 大城桂作, 野田尚昭, 佐野義一, 高 $\mathrm{Si}$ フェライト基地球状黒鉛鋳鉄の引張強度に 及ぼすひずみ速度と温度の影響, 日本鉄鋼協会第 171 回春季講演大会概要集, Vol.29(2016), p.371.

石川信行，小林泰男，豊田政男，切欠きを有する鋼材の変形・破壊特性に及ぼす付加速度の影響, 鉄と鋼, Vol.84, No.2(1998), pp.37-42.

日本工業規格，鋳造品の丸み, JIS B 0703(1987).

日本工業規格, 金属材料引張試験方法, JIS Z 2241(2011).

南二三吉, 橋田知幸, 豊田政男, 森川潤, 大村剛, 有特和茂, 誉田登, ローカルアプローチの適用による構造用鋼 の動的破壊勒性評価, 日本造船学会論文集, No.184(1998), pp.453-464.

Nishitani, H., Mechanics of fracture Vol.5 (1978), Noordhoff International Publishing, Chapter1, p.62.

野田尚昭, 大塚駿, 安藤誠人, 佐野義一, 高瀬康, 篠崎貴宏, 管文海, 高速引張試験における切欠き試験片の動的 応力集中とひずみ速度集中の解析, 日本機械学会論文集 A 編, Vol.79, No.804(2013), pp.1182-1190.

Noda, N. A., Ohtsuka, H., Zheng, H., Sano, Y., Ando, M., Shinozaki, T. and Guan, W., Strain rate concentration and dynamic stress concentration for double-edge-notched specimens subjected to high-speed tensile loads, Figure \& Fracture of Engineering Materials \& Structures, Vol.38, No.1(2015), pp.125-138.

野田尚昭, 高瀬康, 設計に活か寸切欠き・段付き部の材料強度, 日刊工業新聞社(2010).

野田尚昭, 田中賢, 鄭宏彬, 安藤誠人, 佐野義一, 高瀬康, 赤木大地, 高速引張試験の弾塑性解析に基づくポリカ ーボネートの衝撃特性における時間一温度換算則の適用, 自動車技術会論文集, Vol.48, No.2(2017), pp.535542.

岡下勝彦, 大南亮一, 道場康二, 山本晃久, 富松実, 丹治康行, 三木千壽, 兵庫県南部地震による神戸港港湾幹線 道路 p75 橋脚隅角部におけるき裂損傷の原因調査・検討，土木学会論文集, No.591(1998), pp.243-261.

Roebben, G., Lamberty, A. and Pauwels, J., Certification of Charpy V-notch reference test pieces at IRMM, Journal of ASTM International, Vol.2, No7(2015), pp.1-9.

作井誠太, 中村正久, 金属材料の高速衝撃引張試験, 応用物理, Vol.32, No.10(1963), pp.731-742. 
瀬尾健二, 正木順一, シャルピー衝撃試験による溶接部切欠靶性評価に対する一考察, 溶接学会誌, Vol.51, No.3(1982), pp. 291-297.

竹田英俊, 樹脂材料の高速引張試験法, マテリアルライフ学会誌, Vol.20, No.3 (2008), pp. 118-124.

Tanguy, B., Besson, J., Piques, R. and Pineau, A., Ductile to brittle transition of an A508 steel characterized by Charpy impact test: Part II: modeling of the Charpy transition curve. Engineering Fracture Mechanics, Vol.72, No.3 (2005), pp.413-434.

豊田政男, 材料・溶接施工からみた阪神・淡路大震災における建築鉄骨損傷 : 被害から何を学ぶか, まてりあ, Vol.35, No.4(1996), pp.370-379.

Wang, C. M. and Splett, J. D., Uncertainty in reference values for the Charpy V-notch verification program, Journal of Testing and Evaluation, Vol.34, No.3(2005), pp.1-4.

山本博, 小林俊郎, 藤田秀嗣, 球状黒鉛鋳鉄の延性一脆性遷移挙動のひずみ速度依存性, 鋳造工学, Vol.72, No.2(2000), pp.107-112.

山本博, 小林俊郎, 藤田秀嗣, 球状黒鉛鋳鉄における衝撃引張特性の歪速度一温度依存性と延性破壊挙動, 鉄と 鋼, Vol.85, No.10(1999), pp.765-770.

\section{References}

Ando, M., Noda, N.A., Kuroshima, Y., Ishikawa, Y. and Takeda, H., Impact properties of polydimethylsiloxane copolymerized polycarbonate and application of the time-temperature superposition principle, Transactions of the JSME (in Japanese), Vol.80, No.814 (2014), DOI: 10.1299/transjsme.2014smm0149.

Bennett, P. E. and Sinclair, G. M., Parameter representation of low-temperature yield behavior of body-centered cubic transition metals, Transactions of the ASME, Vol.65 (1966), pp.518-524.

Fujii, E., Ohkuma, I., Kawaguchi, Y. and Tsukamoto, M., Effects of temperature and strain rate on dynamic fracture toughness of steel, Transactions of the SNAJ, No.158 (1985), pp.619-629 (in Japanese).

Goto, K., Hirasawa, H. and Toyosada, M., A simple estimating method of constitutive equation for structural steel as a function of strain rate and temperature, The society of naval architects of Japan, Vol.176(1994), pp.501 - 507(in Japanese).

Huh, H., Kim, S.B., Song, J.H. and Lim, J.h., Dynamic tensile characteristics of TRIP-type and DP-type steel sheets for an auto-body, International Journal of Mechanical Sciences, Vol.50 (2008), pp.918-931.

Ikeda, T., Umetani, T., Kai, N., Ogi, K., Noda, N.A. and Sano, Y., Influence of strain rate and temperature on tensile strength of high Si solid solution strengthened ferritic ductile cast iron, Proceedings of The Iron and Steel Institute of Japan 171th Technical Forum, Vol.29(2016), p.371(in Japanese).

Ishikawa, N., Kobayashi, Y. and Toyoda, M., Effect of loading rate on deformation and fracture properties of notched steels, Tetsu-to-Haganè, Vol.84, No.2(1998), pp.37-42(in Japanese).

Japan Industrial Standards, Roundness of Casting, JIS Z 2241 (1987) (in Japanese).

Japan Industrial Standards, Metallic materials-Tensile testing-Method of test at room temperature, JIS Z 2241 (2011)(in Japanese).

Minami, F., Hashida, T., Toyoda, M., Morikawa, J., Ohmura, T., Arimochi, K. and Konda, N., Dynamic fracture toughness evaluation of structural steels based on the local approach, The society of naval architects of Japan, Vol.84(1998), pp.453 -464(in Japanese).

Nishitani, H., Mechanics of fracture Vol.5 (1978), Noordhoff International Publishing, Chapter1, p.62.

Noda, N.A., Ohtsuka H., Ando, M., Sano, Y., Takase, Y., Shinozaki, T. and Guan,W., Analysis of dynamic stress concentration and strain rate concentration for notched specimens used for high speed tensile test, Transactions of the Japan Society of Mechanical Engineers, Series A, Vol.79, No.804(2013), pp.1182-1190(in Japanese).

Noda, N. A., Ohtsuka, H., Zheng, H., Sano, Y., Ando, M., Shinozaki, T. and Guan, W., Strain rate concentration and dynamic stress concentration for double-edge-notched specimens subjected to high-speed tensile loads, Figure \& Fracture of Engineering Materials \& Structures, Vol.38, No.1(2015), pp.125-138.

Noda, N.A. and Takase, Y., Sekkei ni ikasu kirikaki danthukibu no zairyoukyoudo, Nikkankougyoushinbunsha (2010) (in Japanese). 
Noda, N.A., Tanaka, K., Kouhin, T., Ando, M., Sano, Y., Takase, Y. and Akagi, D., Application of the time-temperature superposition principle to the impact property for notched polycarbonate specimens based on the elastic-plastic analysis for high speed tensile test, JSAE Transaction, Vol.48, No.2(2017), pp.535-542 (in Japanese).

Okashita, K., Ohminami, R., Michiba, K., Yamamoto, A., Yomimatsu, M., Tanji, Y. and Miki, C., Investigation of the brittle fracture at the corner of P75 rigid-frame pier in Kobe Harbor Highway during the Hyogoken-Nanbu Earthquake, The Journal of Japan Society of Civil Engineers, No.591(1998), pp.243-261 (in Japanese).

Roebben, G., Lamberty, A. and Pauwels, J., Certification of Charpy V-notch reference test pieces at IRMM. Journal of ASTM International, Vol.2, No7(2015), pp.1-9.

Sakui, S. and Nakamura, T. On impact test of metallic materials, Oyo Buturi, Vol.32, No.10(1963), pp.731-742(in Japanese).

Seo, K. and Masaki, J., Physical interpretation for the upper shelf energy of weld zone in charpy impact test, Journal of the Japan Welding Society, Vol.51, No.3(1982), pp.291 - 297(in Japanese).

Takeda, H., Dynamic tensile strength test of polymeric materials, Journal of Materials Life Society, Vol. 20, No.3 (2008), pp. 118-124 (in Japanese).

Tanguy, B., Besson, J., Piques, R. and Pineau, A., Ductile to brittle transition of an A508 steel characterized by Charpy impact test: Part II: modeling of the Charpy transition curve. Engineering Fracture Mechanics, Vol.72, No.3(2005), pp.413-434.

Toyoda, M., Lessons learned from Great Hanshin Earthquake for steel framed structures with particular reference to materials/welding, Materia Japan, Vol.35, No.4 (1996), pp.370 - 379 (in Japanese).

Wang, C. M. and Splett, J. D., Uncertainty in reference values for the Charpy v-notch verification program, Journal of Testing and Evaluation, Vol.34, No.3 (2005), pp.1-4.

Yamamoto, H., Kobayashi, T. and Fujita, H., Strain rate dependency of ductile-brittle transition behavior in ductile cast iron, Journal of Japan Foundry Engineering Society, Vol.72, No.2(2000), pp.107-112(in Japanese).

Yamamoto, H., Kobayashi, T. and Fujita, H., Strain rate-temperature dependency of impact tensile properties and ductile fracture behavior in ductile cast iron, Tetsu-to-Haganè, Vol.85, No.10 (1999), pp.765-770 (in Japanese). 